\title{
Universiteit
}

Leiden

The Netherlands

\section{Amiloride derivatives and a nonpeptidic antagonist bind at two distinct allosteric sites in the human gonadotropin-releasing hormone receptor}

Heitman, L.H.; Ye, K.; Oosterom, J.; IJzerman, A.P.

\section{Citation}

Heitman, L. H., Ye, K., Oosterom, J., \& IJzerman, A. P. (2008). Amiloride derivatives and a nonpeptidic antagonist bind at two distinct allosteric sites in the human gonadotropin-releasing hormone receptor. Molecular Pharmacology, 73(6), 1808-1815. doi:10.1124/mol.107.043521

Version:

Publisher's Version

License: Licensed under Article 25fa Copyright Act/Law (Amendment Taverne)

Downloaded from: https://hdl.handle.net/1887/3209410

Note: To cite this publication please use the final published version (if applicable). 


\title{
Amiloride Derivatives and a Nonpeptidic Antagonist Bind at Two Distinct Allosteric Sites in the Human Gonadotropin-Releasing Hormone Receptor
}

\author{
Laura H. Heitman, Kai Ye, Julia Oosterom, and Adriaan P. IJzerman \\ Division of Medicinal Chemistry, Leiden/Amsterdam Center for Drug Research, Leiden University, Leiden, the Netherlands \\ (L.H.H., K.Y., A.P.IJ.); and Pharmacology Department, Organon BioSciences, Oss, The Netherlands (J.O.)
}

Received November 15, 2007; accepted March 14, 2008

\begin{abstract}
The interest in the allosteric modulation of $\mathrm{G}$ protein-coupled receptors has grown during the past decade. It has been shown that ligands acting at allosteric sites present in these important drug targets have the ability to modulate receptor conformations and fine-tune pharmacological responses to the orthosteric ligand. In the present study, allosteric modulation of the human gonadotropin-releasing hormone $(\mathrm{GnRH})$ receptor by amiloride analogs [e.g., 5-( $\mathrm{N}, \mathrm{N}$-hexamethylene)amiloride (HMA)] and a nonpeptide antagonistic furan derivative (FD-1) was studied. First, the compounds' ability to influence the dissociation of a radiolabeled peptide agonist ( ${ }^{125}$ I-triptorelin) from human $\mathrm{GnRH}$ receptors stably expressed in Chinese hamster ovary cell membranes was investigated. HMA and FD-1, but not 5-( $N$-benzyl- $N$ methylaminomethyl)1-(2,6-difluorobenzyl)-6-[4-(3-methoxyureido)phenyl]-3-phenylthieno[2,3-d]pyrimidine-2,4(1H,3H)-dione (TAK-013), another nonpeptide antagonist, were shown to in-
\end{abstract}

crease the dissociation rate of ${ }^{125}$-triptorelin, revealing their allosteric inhibitory characteristics. The simultaneous addition of HMA and FD-1 resulted in an additive effect on the dissociation rate. Second, in a functional assay, it was shown that HMA was a noncompetitive antagonist and that FD-1 had both competitive and noncompetitive antagonistic properties. Equilibrium displacement studies showed that the inhibition of ${ }^{125}$ I-triptorelin binding by FD-1 was not affected by HMA. Furthermore, the potency of HMA to increase radioligand dissociation was not affected by the presence of FD-1. Simulation of the data obtained in the latter experiment also indicated neutral cooperativity between the binding of HMA and FD-1. Taken together, these results demonstrate that HMA and FD-1 are allosteric inhibitors that bind at two distinct, noncooperative, allosteric sites. This presence of a second allosteric site may provide yet another opportunity for the discovery of new ligands for the human $\mathrm{GnRH}$ receptor.
The gonadotropin-releasing hormone $(\mathrm{GnRH})$ receptor belongs to the rhodopsin-like subfamily (class A) of G proteincoupled receptors (GPCRs) (Millar et al., 2004). Activation of the $\mathrm{GnRH}$ receptor results in the biosynthesis and secretion of the gonadotropins luteinizing hormone and follicle-stimulating hormone. The gonadotropins bind to their respective receptors on the gonadal cells, which stimulates germ cell development and hormone secretion in the ovaries (Rhoades and Pflanzer, 1996). GnRH, also named luteinizing hormonereleasing hormone, is a linear hypothalamic decapeptide (Fig. 1) and was first isolated and characterized by Schally et

Article, publication date, and citation information can be found at http://molpharm.aspetjournals.org.

doi:10.1124/mol.107.043521. al. (1971). Several peptidic agonists and antagonists for the $\mathrm{GnRH}$ receptor have been approved for the treatment of a variety of sex-hormone-dependent diseases, such as prostate and breast cancer and endometriosis (Conn and Crowley, 1994; Kiesel et al., 2002). Superagonists, a somewhat ambiguous term for continually administered peptidic agonists, are used to desensitize and down-regulate the $\mathrm{GnRH}$ receptor, resulting in gonadal suppression. Such use of agonists, however, produces an initial hormonal "flare," resulting in a temporary activation of the pituitary, which can be prevented by giving peptidic antagonists instead. However, peptidic compounds often need to be administered by parenteral (subcutaneous or intramuscular) injection (Kiesel et al., 2002). Therefore, intensive efforts have been initiated to develop

ABBREVIATIONS: GnRH, gonadotropin-releasing hormone; GPCR, G protein-coupled receptor; HMA, 5-( $N, N$-hexamethylene)amiloride; FD-1, furan derivative-1 [5-(3,5,5,8,8-pentamethyl-5,6,7,8-tetrahydro-naphthalen-2-yloxy)-furan-2-carboxylic acid (2,4,6-trimethoxy-pyrimidin-5-yl)amide]; MIBA, 5-( $N$-methyl- $N$-isobutyl)amiloride; DCB, dichlorobenzamil ; PD81,723, (2-Amino-4,5-dimethyl-3-thienyl)-[3-(trifluoromethyl)phenyl] methanone; SCH-202676, ( $N$-(2,3-diphenyl-1,2,4-thiadiazol-5(2H)-ylidene)methanamine; TAK-013, 5-( $N$-benzyl- $N$-methylaminomethyl)1-(2,6-difluorobenzyl)-6-[4-(3-methoxyureido)phenyl]-3-phenylthieno[2,3- $d$ ]pyrimidine-2,4(1H,3H)-dione; BSA, bovine serum albumin; CHO, Chinese hamster ovary; NFAT, nuclear factor of activated T cell; PBS, phosphate-buffered saline; CMPD-1, 5-[(3,5,5,8,8-pentamethyl-5,6,7,8-tetrahydro-2naphthalenyl)methyl]- $N$-(2,4,6-trimethoxyphenyl)-2-furamide. 
nonpeptidic antagonists, which have the potential to become orally available drugs (Armer and Smelt, 2004).

In the past decade, several classes of nonpeptidic GnRH receptor antagonists have been reported (e.g., Imada et al., 2006; DeVita et al., 1999; Chu et al., 2001; Pontillo et al., 2005). These ligands compete with a peptidic agonist for the same binding site on the receptor, providing evidence that they can be classified as orthosteric ligands. In addition, mutational analysis of the $\mathrm{GnRH}$ receptor has shown that these nonpeptidic antagonists have overlapping but nonidentical binding sites (Betz et al., 2006). The orthosteric binding site of a GPCR has been defined as the site that is recognized by the endogenous ligand (May et al., 2007). For several GPCRs, however, another (allosteric) binding site has been identified [e.g., for muscarinic receptors (Class A), the corticotropin-releasing factor ${ }_{1}$ receptor (class B), and glutamate receptors (Class C) (for reviews, see Christopoulos and Kenakin, 2002; and Soudijn et al., 2004)]. Compared with conventional orthosteric ligands, allosteric modulators can have the therapeutic advantage of greater selectivity and tissue specificity. In addition, the risk of overdose is diminished by their saturability.

In the present study, the allosteric modulation of the human GnRH receptor was examined. Equilibrium and kinetic radioligand binding experiments were performed in the presence and absence of both nonspecific [e.g., 5-( $N, N$-hexamethylene)amiloride (HMA)] and GnRH receptor-selective allosteric modulators [furan derivative-1 (FD-1)] (Fig. 1). Amiloride derivatives have been well described as allosteric inhibitors for different GPCRs at concentrations in the high micromolar range (Gao and IJzerman, 2000), whereas FD-1 is a derivative of a recently described allosteric inhibitor for the $\mathrm{GnRH}$ receptor (Sullivan et al., 2006). The ability of a compound to modulate the dissociation rate of ${ }^{125}$ I-triptorelin was used as a measure for allosteric modulation. This revealed that there are two rather than one allosteric binding sites on this receptor. This emerging concept of multiple allosteric sites may offer further options to modulate GPCR activity.

GnRH pGlu-His-Trp-Ser-Tyr-Gly-Leu-Arg-Pro-Gly. $\mathrm{NH}_{2}$

Triptorelin pGlu-His-Trp-Ser-Tyr-D-Trp-Leu-Arg-Pro-Gly. $\mathrm{NH}_{2}$

Ganirelix D-Nal-D-Phe-D-Pal-Ser-Tyr-D-hArg-Leu-hArg-Pro-D-Ala

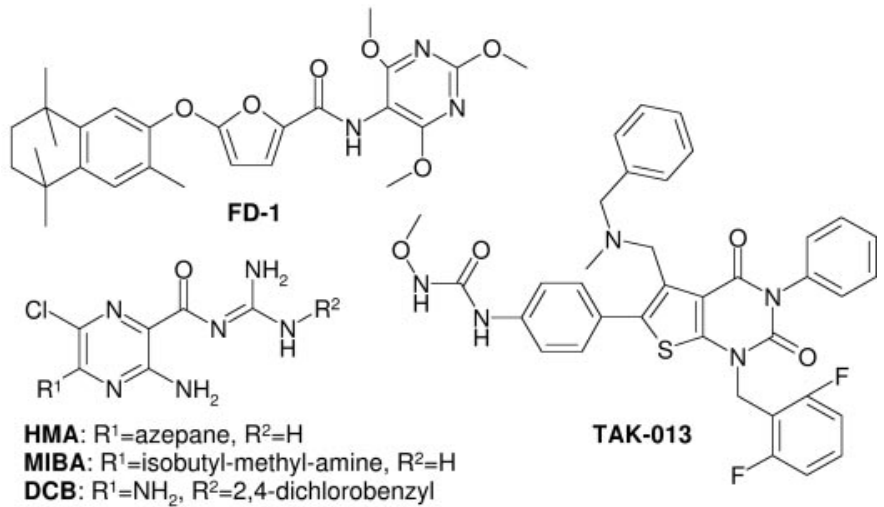

Fig. 1. Sequences of $\mathrm{GnRH}$, triptorelin (agonists), ganirelix (antagonist), and chemical structures of FD-1 (antagonist and allosteric inhibitor), HMA, MIBA, DCB (allosteric inhibitors), and TAK-013 (antagonist).

\section{Materials and Methods}

Materials. GnRH, triptorelin, guanosine- 5 '-triphosphate (GTP) and HMA were purchased from Sigma Aldrich Chemie B.V. (Zwijndrecht, The Netherlands). Amiloride, 5 -( $N$-methyl- $N$-guanidinocarbonylmethyl)amiloride, 5 -( $N$-methyl- $N$-isobutyl)amiloride (MIBA), phenamil, benzamil, and dichlorobenzamil (DCB) were kindly provided by Dr E. J. Cragoe (Lansdale, USA) and were synthesized as described previously (Cragoe et al., 1967). Suramin was a generous gift from Bayer AG (Wuppertal, Germany). PD81,723 and SCH202676 were synthesized in our own laboratory as described by van der Klein et al. (1999) and van den Nieuwendijk et al. (2004). Ganirelix was provided by Organon BioSciences (Oss, The Netherlands). TAK-013 and FD-1 were prepared according to literature procedures (Furuya et al., 1997; Sun et al., 2002). Bovine serum albumin (BSA; fraction V) was purchased from Sigma (St. Louis, MO), whereas bicinchoninic acid (BCA) protein assay reagent was from Pierce Chemical Company (Rockford, IL). ${ }^{125}$ I-triptorelin (specific activity, $2200 \mathrm{Ci} / \mathrm{mmol}$ ) was purchased from PerkinElmer Life Sciences (Groningen, The Netherlands). Chinese hamster ovary (CHO) cells stably expressing the human GnRH receptor was obtained from Euroscreen (Brussels, Belgium). The CHO-K1 cells expressing the wild-type human GnRH receptor and nuclear factor of activated $\mathrm{T}$ cell luciferase reporter gene (NFAT-luc) were provided by Organon BioSciences (Oss, The Netherlands). All other chemicals and cell culture materials were obtained from standard commercial sources.

Cell Culture. CHO cells stably expressing the human $\mathrm{GnRH}$ receptor were grown in Ham's F12 medium containing $10 \%(\mathrm{v} / \mathrm{v})$ normal adult bovine serum, streptomycin $(100 \mu \mathrm{g} / \mathrm{ml})$, penicillin (100 $\mathrm{IU} / \mathrm{ml})$, and $\mathrm{G} 418(0.4 \mathrm{mg} / \mathrm{ml})$ at $37^{\circ} \mathrm{C}$ in $5 \% \mathrm{CO}_{2}$ (Oosterom et al., 2005). The cells were subcultured twice weekly at a ratio of $1: 20$. For membrane preparation, the cells were subcultured 1:10 and transferred to large 15-cm diameter plates.

Membrane Preparation. Cells were detached from the plates by scraping them into $5 \mathrm{ml}$ of PBS, collected, and centrifuged at $700 \mathrm{~g}$ (3000 rpm) for $5 \mathrm{~min}$. Pellets derived from 30 plates were pooled and resuspended in $20 \mathrm{ml}$ of ice-cold $50 \mathrm{mM}$ Tris-HCl buffer containing 2 $\mathrm{mM} \mathrm{MgCl}_{2}, \mathrm{pH}$ 7.4. An UltraTurrax (Heidolph Instruments, Schwabach, Germany) was used to homogenize the cell suspension. Membranes and the cytosolic fraction were separated by centrifugation at $100,000 \mathrm{~g}(31,000 \mathrm{rpm})$ in an Optima LE-80K ultracentrifuge (Beckman Coulter, Fullerton, CA) at $4^{\circ} \mathrm{C}$ for $20 \mathrm{~min}$. The pellet was resuspended in $10 \mathrm{ml}$ of the Tris buffer, and the homogenization and centrifugation step was repeated. Tris buffer $(10 \mathrm{ml})$ was used to resuspend the pellet and the membranes were stored in 250- and $500-\mu \mathrm{l}$ aliquots at $-80^{\circ} \mathrm{C}$. Membrane protein concentrations were measured using the BCA method with BSA as a standard (Smith et al., 1985).

Radioligand Displacement and Saturation Assays. Membrane aliquots containing 5 to $7.5 \mu \mathrm{g}$ of protein were incubated in a total volume of $100 \mu \mathrm{l}$ of assay buffer [25 mM Tris $\mathrm{HCl}, \mathrm{pH} 7.4$, supplemented with $2 \mathrm{mM} \mathrm{MgCl}_{2}$ and $0.1 \%(\mathrm{w} / \mathrm{v}) \mathrm{BSA}$ ] at $22^{\circ} \mathrm{C}$ for 45 min. For saturation experiments, unlabeled triptorelin was spiked with $20 \%{ }^{125}$ I-triptorelin resulting in final concentrations of 0.1 to 3 $\mathrm{nM}$. Nonspecific binding was determined at three concentrations of radioligand in the presence of $100 \mu \mathrm{M}$ ganirelix. Displacement experiments were performed using 11 concentrations of competing ligand in the presence of $30,000 \mathrm{cpm}(\sim 0.1 \mathrm{nM}){ }^{125}$ I-triptorelin. Here, nonspecific binding was determined in the presence of $1 \mu \mathrm{M}$ ganirelix and represented approximately $15 \%$ of the total binding. Incubations were terminated by dilution with ice-cold Tris-HCl buffer. Separation of bound from free radioligand was performed by rapid filtration through Whatman GF/B filters presoaked with $0.25 \%$ polyethylenimine (PEI) for $1 \mathrm{~h}$ using a Brandel harvester. Filters were subsequently washed three times with $2 \mathrm{ml}$ of ice-cold wash buffer (25 mM Tris $\mathrm{HCl}, \mathrm{pH} 7.4$, supplemented with $2 \mathrm{mM} \mathrm{MgCl}_{2}$ and $0.05 \%$ BSA). Filter-bound radioactivity was determined in a $\gamma$-counter (Wizard 1470; PerkinElmer Life and Analytical Sciences). 
Radioligand Kinetic Association and Dissociation Assays. Association experiments were performed by incubating membrane aliquots containing 5 to $7.5 \mu \mathrm{g}$ of protein in a total volume of $100 \mu \mathrm{l}$ of assay buffer (25 mM Tris-HCl, pH 7.4, supplemented with $2 \mathrm{mM}$ $\mathrm{MgCl}_{2}$ and $0.1 \% \mathrm{BSA}$ ) at $22^{\circ} \mathrm{C}$ with $30,000 \mathrm{cpm}$ of ${ }^{125} \mathrm{I}$-triptorelin. The amount of radioligand bound to the receptor was measured at different time intervals during incubation for $90 \mathrm{~min}$. Dissociation experiments were performed by preincubating membrane aliquots containing 5 to $7.5 \mu \mathrm{g}$ of protein in a total volume of $100 \mu \mathrm{l}$ of assay buffer (25 mM Tris-HCl, pH 7.4, supplemented with $2 \mathrm{mM} \mathrm{MgCl}_{2}$ and $0.1 \% \mathrm{BSA})$ at $22^{\circ} \mathrm{C}$ for $45 \mathrm{~min}$ with $30,000 \mathrm{cpm}(\sim 0.1 \mathrm{nM})$ of ${ }^{125}$ I-triptorelin. After preincubation, dissociation was initiated by addition of $1 \mu \mathrm{M}$ ganirelix in the presence or absence (control) of HMA, MIBA, DCB, FD-1, or TAK-013 in a total volume of $5 \mu \mathrm{l}$. The amount of radioligand still bound to the receptor was measured at various time intervals for a total of $2 \mathrm{~h}$. Incubations were terminated and samples were obtained and analyzed as described under Radioligand Displacement and Saturation Assays.

Competitive Kinetic Radioligand Dissociation Assays. Dissociation experiments were mainly performed as described above. After preincubation, dissociation was initiated by addition of $1 \mu \mathrm{M}$ ganirelix in the presence or absence (control) of different concentrations FD-1 $(1,3$, or $10 \mu \mathrm{M})$ and in the presence or absence (control) of six different concentrations of HMA $(5-100 \mu \mathrm{M})$ in a total volume of $5 \mu \mathrm{l}$. The amount of radioligand still bound to the receptor was measured after $30 \mathrm{~min}$. Incubations were terminated and samples were obtained and analyzed as described under Radioligand Displacement and Saturation Assays.

Luciferase Assays. CHOhGnRH_luc cells were cultured as described under Cell Culture. However, Dulbecco's modified Eagle's medium was added to the culture medium (1:1 with F12). On the day of the assay, cells were washed with PBS and then harvested using trypsol $(0.25 \%(\mathrm{w} / \mathrm{v})$ in PBS containing $4.4 \mathrm{mM}$ EDTA). Cells were resuspended in assay medium consisting of DMEM and Ham's F-12 (1:1) supplemented with $1 \mu \mathrm{g} / \mathrm{ml}$ insulin and $5 \mu \mathrm{g} / \mathrm{ml}$ apo-transferrin. Typically, a well-contained $30 \mu \mathrm{l}$ of a certain concentration triptorelin, $30 \mu \mathrm{l}$ of modulator (HMA or FD-1) or assay medium (control), and $30 \mu \mathrm{l}$ cell suspension containing $7.5 \times 10^{5}$ cells $/ \mathrm{ml}$. After $4 \mathrm{~h}$ stimulation, $50 \mu \mathrm{l}$ of luclite (PerkinElmer Life and Analytical Sciences) was added to each well for detection of luciferase protein and plates were left at room temperature for $30 \mathrm{~min}$ in the dark. Finally, the luminescence signal was quantified on the Microbeta Trilux 1450 Luminescence Counter (PerkinElmer Life and Analytical Sciences).

Data Analysis. All binding data were analyzed using the nonlinear regression curve-fitting program Prism v. 5.00 (GraphPad Software Inc., San Diego, CA). $\mathrm{EC}_{50}$ values were directly obtained from the dose-response curves and inhibitory binding constants $\left(K_{\mathrm{i}}\right.$ values) were derived from the $\mathrm{IC}_{50}$ values according to $K_{\mathrm{i}}=\mathrm{IC}_{50} /\left(1+[\mathrm{C}] / K_{\mathrm{d}}\right)$ where $[\mathrm{C}]$ is the concentration of the radioligand and $K_{\mathrm{d}}$ is its dissociation constant (Cheng and Prusoff, 1973). The $K_{\mathrm{d}}$ value of ${ }^{125}$ I-triptorelin at CHOhGnRH membranes was obtained by computer analysis of saturation curves. Dissociation constants, $k_{\text {off }}$, were obtained by computer analysis of the exponential decay of the percentage of ${ }^{125} \mathrm{I}$-triptorelin bound to the receptor. Association rates were calculated according to the equation $k_{\text {on }}=\left(k_{\text {obs }}-k_{\text {off }}\right) /[\mathrm{L}]$, where $k_{\text {obs }}$ was obtained by computer analysis of the exponential association of the percentage of ${ }^{125} \mathrm{I}$-triptorelin bound to the receptor and $[\mathrm{L}]$ is the amount of radioligand used for the association experiments. The $\mathrm{EC}_{50}$ from competitive dissociation experiments was obtained from dose-response curves of enhanced dissociation by different concentrations of HMA, where the nonspecific binding was set at $0 \%$ and either the true control (buffer) or own control binding (1, 3, or $10 \mu \mathrm{M}$ FD-1) after 30 min was set at $100 \%$. All values obtained are means of at least three independent experiments performed in duplicate.

Simulation of Cooperativity between FD-1 and HMA. A mathematical model (eq. 1) for two distinct allosteric sites (Lazareno et al., 2000) was implemented in MatLab (version 7.1) to simulate the effects of different cooperativities between HMA and FD-1 on the $\mathrm{EC}_{50}$ of HMA in enhancing ${ }^{125}$ I-triptorelin dissociation.

$$
\mathrm{EC}_{50}^{\text {HMA }}=\frac{1+[\mathrm{FD}-1] \times K_{\mathrm{FD}-1}^{\text {Triptorelin }}}{K_{\mathrm{HMA}}^{\text {Triptorelin }} \times\left(1+[\mathrm{FD}-1] \cdot K_{\mathrm{FD}-1}^{\text {Triptorelin }} \times \delta\right)}
$$

in which $\mathrm{EC}_{50}^{H M A}$ is the observed $\mathrm{EC}_{50}$ of HMA in enhancing ${ }^{125} \mathrm{I}$ triptorelin binding. $K_{\mathrm{FD}-1}^{\text {triptorelin }}$ and $K_{\mathrm{HMA}}^{\text {tiptorelin }}$ are the affinities on the triptorelin-occupied receptor for FD-1 and HMA, respectively. $\delta$ is the parameter defining the cooperativity between HMA and FD-1.

\section{Results}

Radioligand Saturation Experiments. Saturation experiments were performed with unlabeled triptorelin spiked with $20 \%{ }^{125}$ I-triptorelin on $\mathrm{CHO}$ cells expressing the human $\mathrm{GnRH}$ receptor. The results of a representative saturation experiment are shown in Fig. 2. Although the nonspecific binding was high, the receptor binding of ${ }^{125}$ I-triptorelin was saturable and best characterized by a one-site receptor model. Dissociation constant $\left(K_{\mathrm{D}}\right)$ and $B_{\max }$ values of 0.35 (0.33-0.37) $\mathrm{nM}$ and 217 (207-227) fmol/mg protein, respectively, were obtained from two independent saturation experiments. The $K_{\mathrm{D}}$ value for ${ }^{125}$ I-triptorelin obtained with these experiments was used to derive $K_{\mathrm{i}}$ rather than $\mathrm{IC}_{50}$ values, as described in the next section.

Radioligand Displacement Assays. Experiments were performed to assess the ability of various ligands to compete with the binding of ${ }^{125}$ I-triptorelin to $\mathrm{CHOhGnRH}$ cell membranes were performed with different ligands. The endogenous agonist $(\mathrm{GnRH})$, a derivative (triptorelin), a peptidic antagonist (ganirelix), and two nonpeptidic antagonists (TAK-013 and FD-1) (Fig. 1), were used to displace radioligand binding. The displacement curves and affinity values are shown in Fig. 3 and Table 1, respectively. All ligands were able to fully displace ${ }^{125} \mathrm{I}$-triptorelin with affinities ranging from $0.42 \mathrm{nM}$ for triptorelin to $4.9 \mathrm{nM}$ for FD-1. From Fig. 3, it follows that the curve of GnRH had a smaller Hill coefficient than that of the other ligands. Computational analysis indeed showed that it was best described by a twosite competition model with a higher $\left(K_{\mathrm{H}}\right)$ and a lower affinity $\left(K_{\mathrm{L}}\right)$ of $0.54 \pm 0.004$ and $21 \pm 10 \mathrm{nM}$ (mean \pm S.E.M., $n=$ 3 ), respectively, with $69 \pm 3 \%$ of high-affinity receptors.

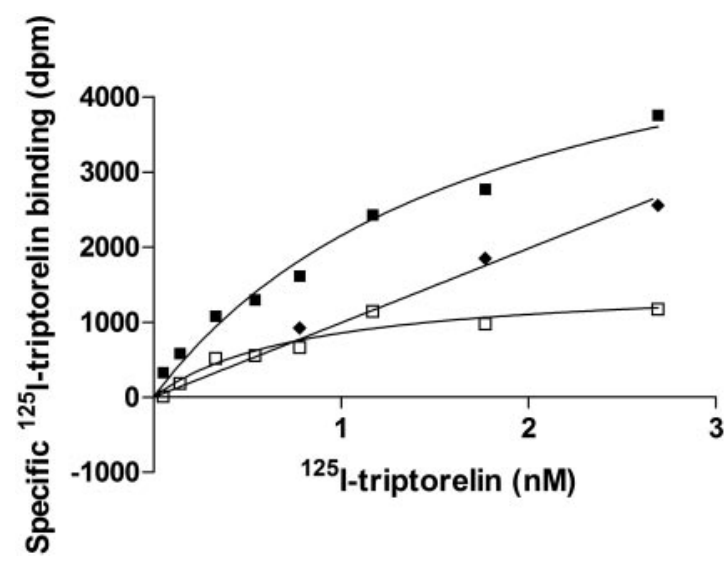

Fig. 2. Saturation of ${ }^{125} \mathrm{I}$-triptorelin binding to human gonadotropinreleasing hormone receptors. The specific binding $(\square)$ was determined by subtracting the nonspecific binding $(\diamond)$ from the total binding $(\square)$. The $K_{\mathrm{D}}$ value was $0.35(0.33-0.37) \mathrm{nM}$ and the $B_{\max }$ value was $217(207-227)$ $\mathrm{fmol} / \mathrm{mg}$ protein. Representative graphs from one experiment performed in duplicate. 
Allosteric Modulation ${ }^{125}$ I-triptorelin Binding. The effect of some allosteric modulators was tested on equilibrium binding of ${ }^{125}$ I-triptorelin. As shown in Fig. $4 \mathrm{a}$, PD81,723, a selective adenosine $A_{1}$ receptor modulator, had no effect on radioligand binding to the $\mathrm{GnRH}$ receptor. The addition of GTP, suramin, and sodium ions had a modest effect on the binding of ${ }^{125}$ I-triptorelin. Both SCH-202676 and HMA (Fig. 1), however, had a detrimental effect on radioligand binding, because almost no radioactivity was detected after incubation with these agents. To investigate the effects of HMA and other amiloride derivatives, a similar experiment was performed with amiloride, 5-( $N$-methyl- $N$-guanidinocarbonylmethyl)amiloride, MIBA, phenamil, benzamil, and DCB. From Fig. 4b, it follows that most amilorides had little effect and that only MIBA and DCB were able to inhibit ${ }^{125} \mathrm{I}$ triptorelin binding. Therefore, displacement of ${ }^{125}$ I-triptorelin equilibrium binding by HMA, MIBA, and DCB at different concentrations was determined (Fig. 5). The obtained inhibition curves were best described by a one-site receptor model and resulted in similar potencies for $\mathrm{HMA}\left(\mathrm{IC}_{50}=\right.$ $29 \pm 3 \mu \mathrm{M}), \operatorname{MIBA}\left(\mathrm{IC}_{50}=39 \pm 7 \mu \mathrm{M}\right)$, and $\mathrm{DCB}\left(\mathrm{IC}_{50}=30 \pm\right.$ $3 \mu \mathrm{M}$ ) with pseudo-Hill coefficients of $1.4 \pm 0.06,1.3 \pm 0.02$, and $1.6 \pm 0.2$, respectively (Table 2 ).

Kinetic Association and Dissociation Experiments. The $K_{\mathrm{D}}$ of ${ }^{125}$ I-triptorelin in the absence of modulators was also derived from kinetic experiments and the resulting dissociation and association rate constants. Equilibrium binding was reached after approximately $45 \mathrm{~min}$ with an association rate constant of $0.28 \pm 0.08 \mathrm{nM}^{-1} \mathrm{~min}^{-1}$. Under control conditions, the radioligand dissociated from the receptor with a dissociation rate constant of $0.021 \pm 0.002 \mathrm{~min}^{-1}$. To-

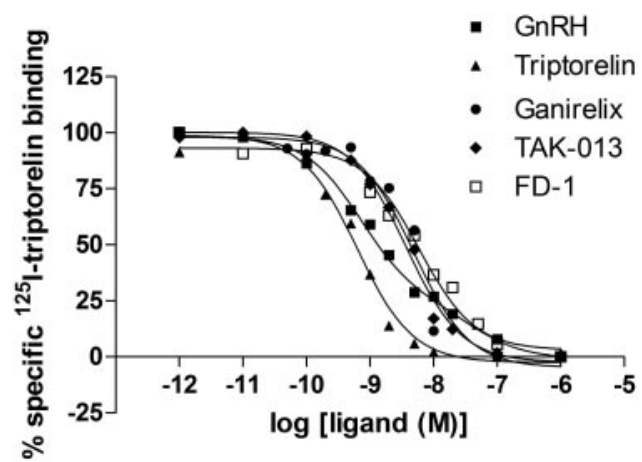

Fig. 3. Displacement of ${ }^{125} \mathrm{I}$-triptorelin from human gonadotropin-releasing hormone receptors stably expressed on $\mathrm{CHO}$ cell membranes by $\mathrm{GnRH}$, triptorelin, ganirelix, TAK-013, and FD-1. Representative graphs from one experiment performed in duplicate (see Table 1 for affinity values).

\section{TABLE 1}

Receptor affinity of peptidic agonists (GnRH and triptorelin), peptidic antagonist (ganirelix), and nonpeptidic antagonists (TAK-013 and FD-1)

$K_{\mathrm{i}}$ represents displacement of specific ${ }^{125} \mathrm{I}$-triptorelin binding from human gonadotropin-releasing hormone receptors stably expressed in $\mathrm{CHO}$ cell membranes. Values are means ( \pm S.E.M.) of at least three separate assays performed in duplicate.

\begin{tabular}{lc}
\hline Compound & $K_{\mathrm{i}}$ \\
\hline & $n M$ \\
GnRH $^{\alpha}$ & $1.2 \pm 0.1$ \\
Triptorelin & $0.42 \pm 0.07$ \\
Ganirelix & $3.8 \pm 0.4$ \\
TAK-013 & $1.9 \pm 0.7$ \\
FD-1 & $4.9 \pm 1$ \\
\hline
\end{tabular}

\footnotetext{
${ }^{a}$ According to computer analysis of the binding curve of GnRH, a two-site competition model of higher $(\mathrm{H})$ and lower $(\mathrm{L})$ affinity was statistically preferred with $K_{\mathrm{H}}=0.54 \pm 0.004 \mathrm{nM}, K_{\mathrm{L}}=21 \pm 10 \mathrm{nM}$, and $\mathrm{R}_{\mathrm{H}}=69 \pm 3 \%$.
}

gether, this resulted in a "kinetic" $K_{\mathrm{D}}$ value of $0.74 \mathrm{nM}$, which was in good agreement with the $K_{\mathrm{D}}$ value $(0.35 \mathrm{nM})$ obtained in the "spiked" saturation analysis. Next, the dissociation kinetics of ${ }^{125}$ I-triptorelin from $\mathrm{CHOhGnRH}$ receptor membranes was determined in the presence of modulator (Fig. 6 and Table 2). All compounds, except TAK-013, increased the dissociation rate compared with the control off-rate, indicative of their allosteric nature and negative modulation of the receptor. The dissociation rate constant of ${ }^{125} \mathrm{I}$-triptorelin was increased 2.5-fold to $0.053 \pm 0.006 \mathrm{~min}^{-1}$ with the addition of $0.1 \mathrm{mM}$ HMA, which was a more potent allosteric inhibitor than MIBA and DCB, although their effect on the equilibrium binding was similar (Table 2). Likewise, the addition of a $3 \mu \mathrm{M}$ concentration of the nonpeptidic antagonist FD-1 resulted in a 3.2 -fold increase of the dissociation rate constant to $0.068 \pm 0.009 \mathrm{~min}^{-1}$. The simultaneous addition
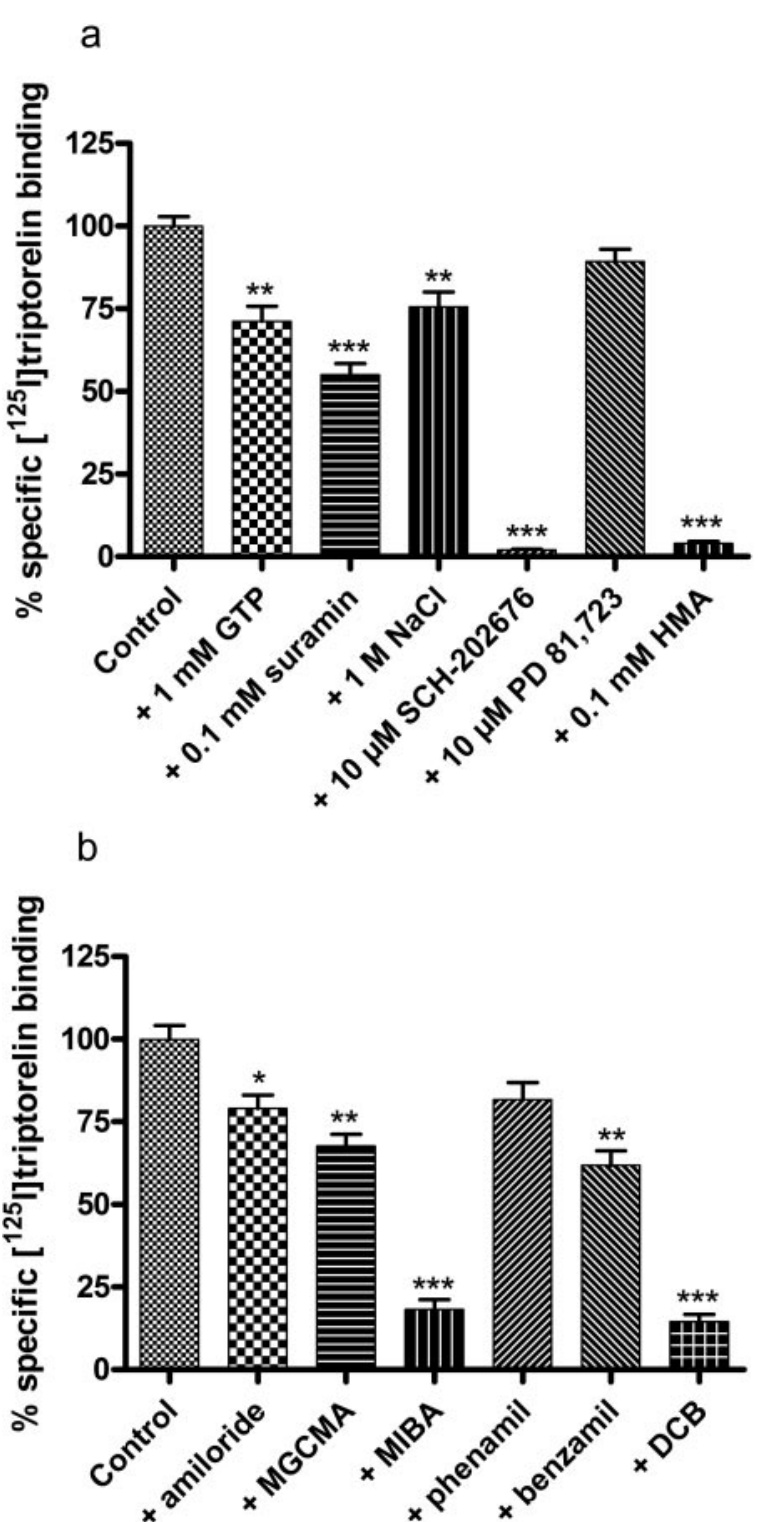

Fig. 4. ${ }^{125}$ I-triptorelin equilibrium binding to human gonadotropin-releasing hormone receptors stably expressed on $\mathrm{CHO}$ cell membranes in the absence (control, 100\%) or presence of GTP, suramin, sodium, SCH-202676, PD 81,723 and HMA (a) and $0.1 \mathrm{mM}$ amiloride derivatives (b). Values are means ( \pm S.E.M.) from at least three independent experiments, performed in duplicate. $(*, p<0.05 ; * *, p<0.01 ; * * *, p<0.001$ versus control.) 
of HMA and FD-1 in the above concentrations resulted in an additive effect on the dissociation rate constant, which increased 5.2-fold under this condition $\left(k_{\text {off }}=0.11 \pm 0.01 \mathrm{~min}^{-1}\right)$.

Allosteric Modulation of Receptor Activation. The effect of HMA and FD-1 on receptor activation by triptorelin was measured using a NFAT-induced luciferase assay (Fig. 7 and Table 3). HMA at three concentrations did not cause a shift in potency of triptorelin $\left(\mathrm{EC}_{50}=0.24 \pm 0.02 \mathrm{nM}\right)$. However, increasing concentrations of HMA resulted in a dose-dependent lowering of the maximal effect $\left(E_{\max }\right)$. For example, the presence of $10 \mu \mathrm{M}$ HMA resulted in an $E_{\max }$ value of $58 \pm 1 \%$ compared with control (100\%). This indicated noncompetitive antagonism, which agrees with the allosteric inhibition seen in the kinetic dissociation experiments. FD-1 at three concentrations caused parallel rightward shifts in the dose-response curves of triptorelin, proof rather of competitive antagonism. However, addition of FD-1 also resulted in a suppression of the $E_{\max }$ value, indicative for its allosteric nature. For example, addition of $3 \mu \mathrm{M}$ FD-1 decreased the $E_{\max }$ value to $72 \pm 5 \%$ of the control value.

Effect of HMA on FD-1 Binding. To determine whether the allosteric effects described above occurred through an interaction at different allosteric sites, displacement of ${ }^{125} \mathrm{I}$ triptorelin by different concentrations of FD-1 was determined in the presence and absence of three concentrations of

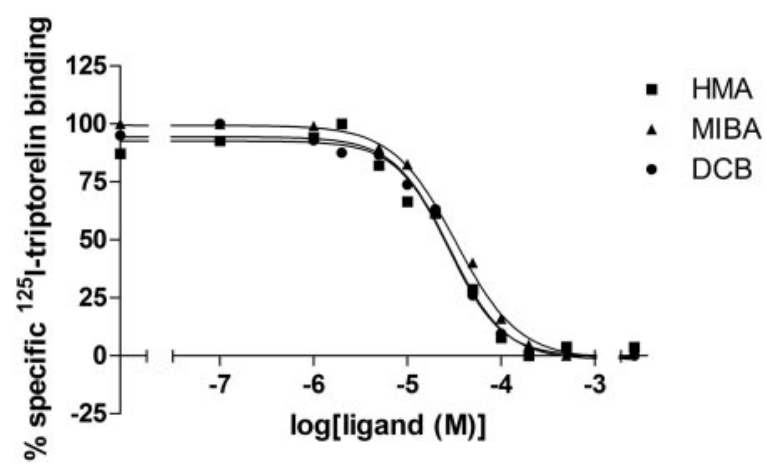

Fig. 5. Inhibition of ${ }^{125}$ I-triptorelin equilibrium binding to human gonadotropin-releasing hormone receptors stably expressed on CHO cell membranes by HMA and MIBA. Representative graphs from one experiment performed in duplicate (see Table 3 for affinity values).

\section{TABLE 2}

Displacement, dissociation, and allosteric modulation of ${ }^{125}$ I-triptorelin binding by HMA, MIBA, DCB, and FD-1

Inhibitory potency is displacement of specific ${ }^{125}$ I-triptorelin binding from human $\mathrm{GnRH}$ receptors stably expressed in CHO cell membranes. The value of the kinetic dissociation rate constant was obtained by analysis of the exponential dissociation curve of ${ }^{125}$ I-triptorelin bound to human gonadotropin-releasing hormone receptors in the presence of buffer (control), 0.1 mM HMA, MIBA, or DCB, $3 \mu \mathrm{M}$ FD-1, or 0.1 mM HMA and $3 \mu \mathrm{M}$ FD-1. The shift is defined as the ratio of $k_{\text {off }}$ values in the presence and absence (control) of modulator, respectively. Modulatory potency is the value for the concentration at half-maximal enhancement of dissociation kinetics. alues are means ( \pm S.E.M.) of at least three separate assays performed in duplicate.

\begin{tabular}{lcccc}
\hline Condition & $\begin{array}{c}\text { Inhibitory } \\
\text { Potency } \\
\text { IC }_{50}\end{array}$ & $k_{\text {off }}$ & Shift $k_{\text {off }}$ & $\begin{array}{c}\text { Modulatory } \\
\text { Potency }_{\text {EC }_{50}}\end{array}$ \\
\hline & $\mu M$ & $\min ^{-1}$ & & $\mu M$ \\
Control & $29 \pm 3$ & $0.053 \pm 0.006$ & 2.5 & $49 \pm 7$ \\
+ HMA & $39 \pm 7$ & $0.045 \pm 0.006$ & 2.1 & N.D. \\
+ MIBA & $30 \pm 3$ & $0.035 \pm 0.006$ & 1.7 & N.D. \\
+ DCB & & $0.068 \pm 0.009$ & 3.2 & $5.0 \pm 1$ \\
+ FD-1 & & $0.11 \pm 0.01$ & 5.2 & \\
+ HMA, + FD-1 & & & &
\end{tabular}

N.D., not determined.
HMA (Fig. 8 and Table 4). It follows from Fig. 8 that the addition of HMA alone (data points on $y$-axis) inhibited the binding of ${ }^{125}$ I-triptorelin dose dependently, as shown by the decrease in $B_{\max }$ in Table 4 and corresponding to the results shown in Fig. 5. FD-1 potently displaced the binding of the radioligand in a concentration-dependent manner. The addition of HMA, however, did not impede the displacement by FD-1. It is noteworthy that, at $30 \mu \mathrm{M}$ HMA, the affinity of FD-1 was significantly increased (Table 4), indicating a possible allosteric interaction between these compounds.

Competitive Dissociation Experiments. Another series of experiments were performed to determine whether

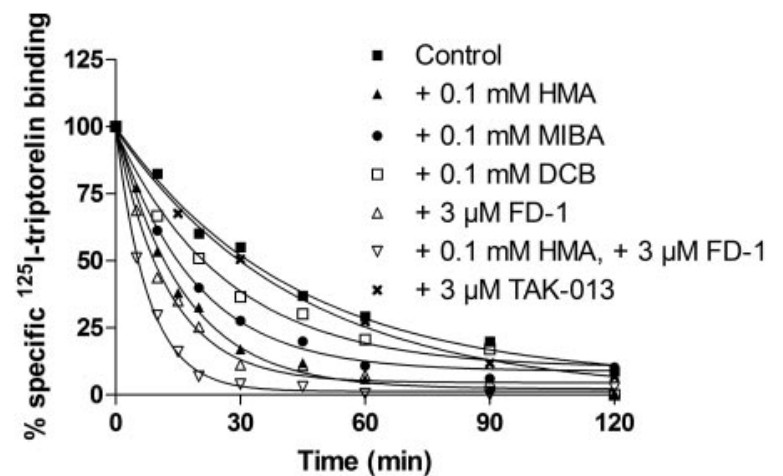

Fig. 6. Dissociation kinetics of ${ }^{125} \mathrm{I}$-triptorelin binding to human gonadotropin-releasing hormone receptors stably expressed on $\mathrm{CHO}$ cell membranes. Dissociation was initiated by either the addition $1 \mu \mathrm{M}$ ganirelix mixed with buffer (control) or modulator. Representative graphs from one experiment performed in duplicate (see Table 2 for kinetic parameters).

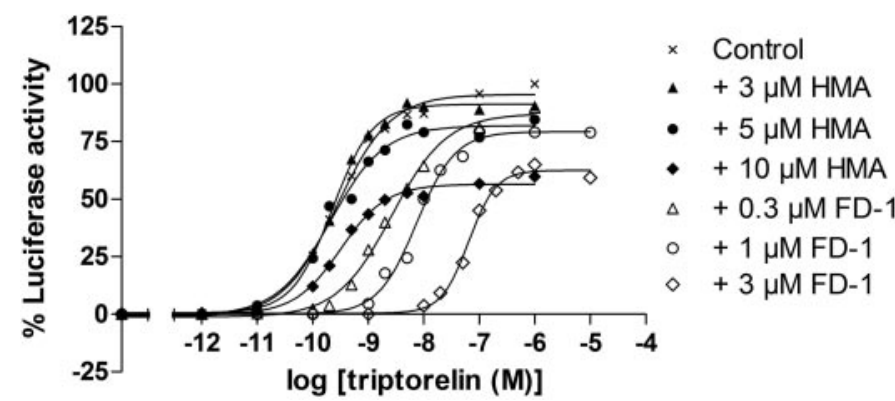

Fig. 7. Concentration-effect curves of triptorelin on NFAT-induced luciferase production through human gonadotropin-releasing hormone receptors in the presence and absence (control) of different concentrations HMA or FD-1. Representative graphs from one experiment performed in duplicate (see Table 3 for $\mathrm{EC}_{50}$ and $E_{\max }$ values).

TABLE 3

Receptor activation by triptorelin in the presence or absence of different concentrations of HMA or FD-1

$\mathrm{Ca}^{2+}$-mediated luciferase activity in $\mathrm{CHO}$ cells that stably express the human gonadotropin-releasing hormone receptor and NFAT-luciferase reporter gene. Values are means ( \pm S.E.M.) of at least three separate assays performed in duplicate.

\begin{tabular}{ccc}
\hline \multirow{2}{*}{ Compound } & \multicolumn{2}{c}{ Activity in Luciferase Assay } \\
\cline { 2 - 3 } & $\mathrm{EC}_{50}$ & $E_{\max }$ \\
\hline & $n M$ & $\%$ \\
Triptorelin & $0.24 \pm 0.02$ & $100 \pm 2$ \\
$+3 \mu$ M HMA & $0.21 \pm 0.03$ & $95 \pm 5$ \\
$+5 \mu$ M HMA & $0.24 \pm 0.03$ & $89 \pm 3^{* * *}$ \\
$+10 \mu$ M HMA & $0.29 \pm 0.02^{*}$ & $58 \pm 1^{* * *}$ \\
$+0.3 \mu$ M FD-1 & $2.7 \pm 0.04^{* * *}$ & $93 \pm 1^{* * *}$ \\
$+1 \mu$ M FD-1 & $10 \pm 2^{* * *}$ & $84 \pm 5^{* * *}$ \\
$+3 \mu$ M FD-1 & $44 \pm 12^{* * *}$ & $72 \pm 5^{* * *}$ \\
\hline
\end{tabular}

$* P<0.05$ versus control.

**** $P<0.001$. 
FD-1 and HMA bound at a different allosteric site. Because FD-1 also acts as an orthosteric antagonist (Fig. 8), "competitive dissociation" experiments were performed solely to study allosteric interactions. The concentration-dependent effect of HMA on ${ }^{125}$ I-triptorelin dissociation was studied in the absence and presence of three concentrations of FD-1 (Fig. 9). The data obtained are represented in two formats. Fig. 9a shows that the addition of FD-1 enhanced the dissociation, and under every condition, HMA dose-dependently further enhanced that dissociation. Figure $9 \mathrm{~b}$ shows that the addition of FD-1 did not affect the modulating potency of HMA $\left(\mathrm{EC}_{50}=49 \pm 7 \mu \mathrm{M}\right)$, which indicates a noncompetitive interaction of these two compounds. It is noteworthy that FD-1 has a 10-fold higher modulating potency than HMA: $5.0 \pm 1 \mu \mathrm{M}$ (Table 2).

Simulation of Cooperativity between FD-1 and HMA. Eq. 1 under Materials and Methods, taken from Lazareno et al. (2000), was used to simulate the effects of different cooperativities between HMA and FD-1 on the potency of HMA in enhancing the ${ }^{125}$ I-triptorelin dissociation. When $\delta=1$, the binding of two allosteric modulators is noninteracting (neutral cooperativity). When $\delta<1$ or $\delta>1$, they exhibit either negative (competitive) or positive (enhancement) cooperativity. These simulations, shown in Fig. 10, demonstrate that the data points we had gathered comply with a $\delta$ value of 1 , thus indicating a neutral cooperativity between the binding of HMA and FD-1.

\section{Discussion}

In the present study, it was demonstrated that human GnRH receptors are allosterically modulated by amiloride

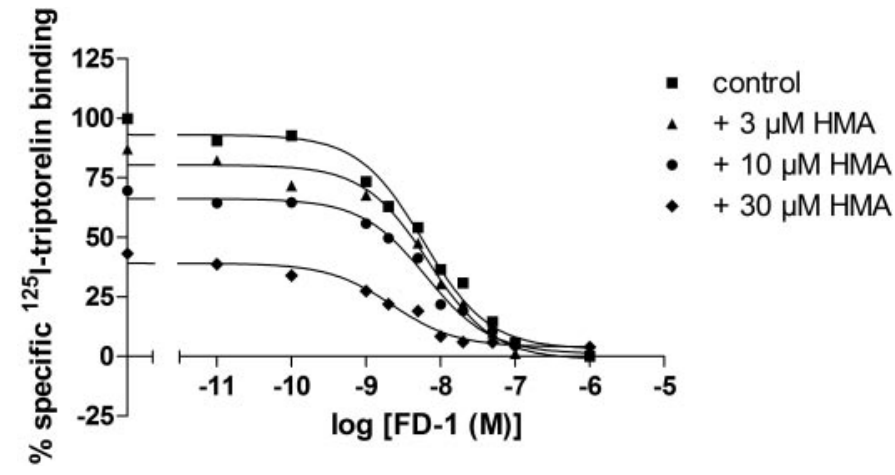

Fig. 8. Displacement of ${ }^{125}$ I-triptorelin by FD-1 binding at human gonadotropin-releasing hormone receptors stably expressed on $\mathrm{CHO}$ cell membranes in the presence or absence (control) of three concentrations of HMA. Representative graphs from one experiment performed in duplicate (see Table 4 for affinity and $B_{\max }$ values).

\section{TABLE 4}

Receptor affinity of FD-1 and radioligand binding capacity (in the absence of FD-1) in the presence or absence of different concentrations of HMA

Displacement of specific ${ }^{125}$ I-triptorelin binding from human gonadotropin-releasing hormone receptors stably expressed in $\mathrm{CHO}$ cell membranes. Values are menas $( \pm$ S.E.M.) of at least three separate assays performed in duplicate.

\begin{tabular}{ccc}
\hline \multirow{2}{*}{ Compound } & \multicolumn{2}{c}{${ }^{125}$ I-Triptorelin Displacement $^{\mathrm{a}}$} \\
\cline { 2 - 3 } & $K_{\mathrm{i}}$ & $B_{\max }$ \\
\hline & $n M$ & $\%$ \\
FD-1 & $4.9 \pm 1$ & $100 \pm 5$ \\
$+3 \mu \mathrm{M}$ HMA & $5.9 \pm 2$ & $87 \pm 5^{*}$ \\
$+10 \mu \mathrm{M}$ HMA & $5.3 \pm 1$ & $75 \pm 6^{* *}$ \\
$+30 \mu \mathrm{M}$ HMA & $2.3 \pm 0.7^{*}$ & $47 \pm 5^{* * *}$ \\
\hline
\end{tabular}

$* P<0.05$ versus control.

$* * * P<0.001$. derivatives and a nonpeptidic antagonist (FD-1). Radioligand displacement assays were performed in which four reference compounds were tested (Fig. 3 and Table 1). For GnRH, a shallow displacement curve was obtained that was best fit
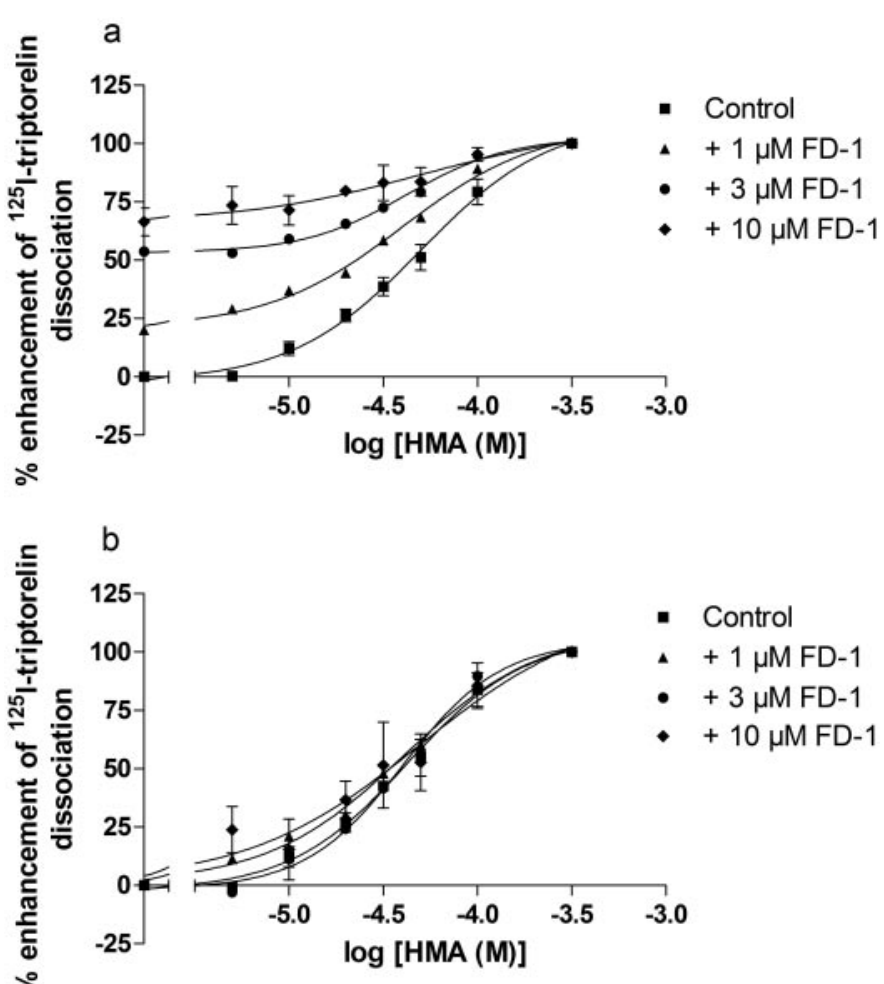

Fig. 9. Effect of HMA on single point dissociation of ${ }^{125}$ I-triptorelin from human gonadotropin-releasing hormone receptors stably expressed on $\mathrm{CHO}$ cell membranes in the presence or absence (control) of three concentrations of FD-1. The top graph (a) shows data normalized to the control measured in the absence of FD-1 and the bottom graph (b) shows data normalized to the four conditions in the absence of HMA. Graphs are mean \pm S.E.M. from at least four independent experiments, performed in duplicate.

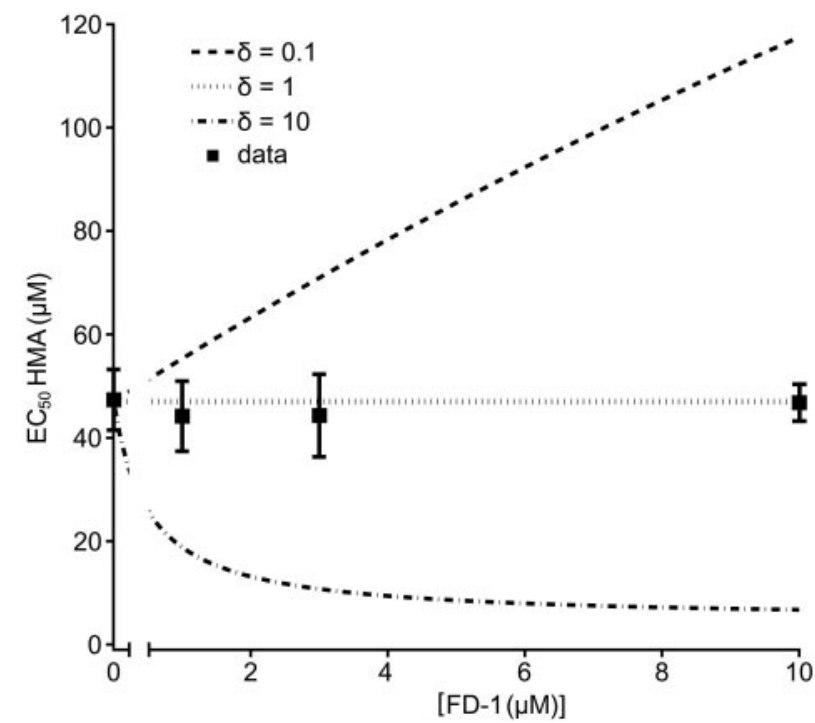

Fig. 10. Neutral cooperativity between HMA and FD-1 in enhancing ${ }^{125} \mathrm{I}$ triptorelin dissociation. The experimental data of different concentrations of FD-1 affecting the modulating potency of HMA is displayed with standard deviation. The lines show the fit of the data to eq. 1 (see Materials and Methods), where the situations are simulated that two compounds exhibit positive $(\delta>1)$, neutral $(\delta=1)$ and negative cooperativity $(\delta<1)$. 
with a two-site competition model. In the presence of $1 \mathrm{mM}$ GTP, the favored mode of binding for GnRH shifted toward a one-site competition model with a $K_{\mathrm{i}}$ value of $18 \pm 0.6 \mathrm{nM}$ (data not shown). Note that the latter affinity equals the affinity found for the low-affinity receptors in the absence of $\operatorname{GTP}\left(K_{\mathrm{L}}=21 \pm 10 \mathrm{nM}\right)$. This can be explained by the ternary complex model, in which the presence of GTP causes a shift to a higher $K_{\mathrm{i}}$ value through uncoupling of the receptor from the $\mathrm{G}$ protein (Lefkowitz et al., 1981). It is noteworthy that triptorelin binding was best described by a one-site competition model, although the presence of GTP did decrease radioligand binding (Fig. 4a). Beckers et al. (2001) reported the affinity of $\mathrm{GnRH}$ obtained in a ${ }^{125} \mathrm{I}$-triptorelin displacement assay, where they used whole LTK cells transfected with the human GnRH receptor. A 5-fold lower affinity $(5.4 \pm 1.8 \mathrm{nM})$ was found that may be caused by a higher amount of endogenous GTP present in whole cells. The affinities reported for triptorelin and ganirelix, however, were in good agreement with the affinities reported here (Table 1). For TAK-013, an $\mathrm{IC}_{50}$ value of $2.5 \mathrm{nM}$ was reported (Sasaki et al., 2003), whereas we found a $K_{\mathrm{i}}$ value of $1.9 \pm 0.7 \mathrm{nM}$. Finally, FD-1 was tested, which belongs to a different class of nonpeptidic antagonists (Table 1 ). FD-1 had a $K_{\mathrm{i}}$ value of $4.9 \pm 1 \mathrm{nM}$, which was comparable with the affinity reported for an analog of this compound, CMPD- $1\left(K_{\mathrm{i}}=6.0 \pm 0.8 \mathrm{nM}\right)$ (Anderes et al., 2003).

The modulation of ${ }^{125} \mathrm{I}$-triptorelin binding was explored in the absence and presence of different generally known modulators (Fig. 4a). GTP and suramin are compounds that have an effect on $\mathrm{G}$ protein coupling. It was shown that they had only a modest effect on ${ }^{125}$ I-triptorelin binding. The effect of PD81,723 on the adenosine $A_{1}$ receptor has been extensively studied (Bruns and Fergus, 1990). It has been shown to be a selective allosteric enhancer at the adenosine $A_{1}$ receptor, and, as might be expected, it did not affect ${ }^{125} \mathrm{I}$-triptorelin equilibrium binding to the $\mathrm{GnRH}$ receptor. The influence of a high concentration of sodium ions was also examined at the human GnRH receptor. On other GPCRs (e.g., adenosine $\mathrm{A}_{2 \mathrm{~A}}, \alpha_{2}$-adrenergic, and dopamine $\mathrm{D}_{2}$ receptors), sodium ions have been shown to regulate ligand binding (Horstman et al., 1990; Neve et al., 1991; Gao and IJzerman, 2000). However, on the GnRH receptor, sodium ions do not have such a profound effect. In contrast, HMA, which has been shown at higher micromolar concentrations to modulate the same receptor subtypes as sodium ions (Hoare and Strange, 1996; Gao and IJzerman, 2000; Leppik and Birdsall, 2000), was able to fully inhibit radioligand binding. In addition, $\mathrm{SCH}-$ 202676 was shown to have an effect on equilibrium binding similar to that of HMA. However, this compound was recently shown to be a protein modifier rather than an allosteric modulator (Göblyös et al., 2005). To further explore the modulation of ${ }^{125}$ I-triptorelin binding by HMA, other amiloride derivatives were tested (Fig. 4b). Two other amiloride derivatives, MIBA and DCB, showed inhibition of equilibrium binding. It had been shown previously that MIBA was the most potent of this class of inhibitors next to HMA (Hoare and Strange, 1996; Gao and IJzerman, 2000).

Allosteric inhibition of ${ }^{125}$ I-triptorelin binding was shown by the increase in its dissociation rate from human $\mathrm{GnRH}$ receptors in the presence of HMA or MIBA (Fig. 6). CMPD-1 has recently been shown to be an allosteric inhibitor for the $\mathrm{GnRH}$ receptor too (Sullivan et al., 2006). Previously, that same compound (named Furan-1 or CMPD-1) had been demonstrated to be a potent nonpeptidic antagonist (Anderes et al., 2003), whereas its allosteric effects occur at higher concentrations. FD-1 and CMPD-1 belong to the same class of nonpeptidic antagonists with only some small structural differences (Fig. 1). It was demonstrated that, as for HMA, MIBA, and DCB, FD-1 was also able to increase the dissociation rate (Fig. 6). As mentioned above, HMA was shown to be an allosteric inhibitor on different GPCRs [e.g., at the adenosine $\mathrm{A}_{2 \mathrm{~A}}$ receptor (Gao and IJzerman, 2000)]. The selectivity of FD-1 was therefore tested on this receptor; FD-1 did not modulate the dissociation rate of the $A_{2 \mathrm{~A}}$ receptor radioligand (data not shown). FD-1 is therefore a selective allosteric inhibitor, unlike HMA. The simultaneous addition of HMA and FD-1 resulted in an additive effect on the dissociation rate. However, addition of a high concentration (10 $\mu \mathrm{M})$ of FD-1 further enhanced the dissociation (Fig. 9a). Therefore, this did not indicate per se that the observed additive effect was due to the presence of two allosteric binding sites, although the two compounds are structurally different. The effect on in vitro functional efficacy was also determined (Fig. 7 and Table 3). The functional data showed that HMA is a pure noncompetitive antagonist (allosteric inhibitor) of the effects of triptorelin. On the other hand, FD-1 showed a mixed type of antagonism, indicating both orthosteric and allosteric characteristics. In this assay, HMA and FD-1 showed the same effects when the endogenous ligand GnRH was used (data not shown), even though the binding sites of triptorelin and $\mathrm{GnRH}$ are not identical (Fromme et al., 2001). Furthermore, FD-1 seemed to be a more potent allosteric inhibitor than Furan-1 (Sullivan et al., 2006). To prove that the allosteric characteristics of FD-1 were specific for this nonpeptidic antagonist only, TAK-013 was also examined. It was shown that TAK-013 had no effect on the dissociation rate of ${ }^{125}$ I-triptorelin (Fig. 6). This suggests that the allosteric nature of FD-1 is not a general feature of all nonpeptidic antagonists but was due to structural aspects of FD-1 itself. It is noteworthy that trypan blue exclusion tests showed that cell viability always exceeded $95 \%$, which ruled out that the decrease in maximal response was caused by any cytotoxic effects of the relatively high concentrations of HMA or FD-1. In addition, reversible binding was shown in a luciferase assay, where the cells were preincubated with the highest concentrations used of HMA and FD-1. After washing of the cells according to a method described by Lu and coworkers (2007), full agonist responses were obtained, while unwashed preincubated cells still showed a decreased maximal response.

Finally, we examined whether HMA and FD-1 exert their effect through two distinct allosteric sites on the GnRH receptor. Lazareno et al. (2000) and Lanzafame et al. (2006) have reported two allosteric sites for the $M_{1}$ and $M_{4}$ muscarinic receptor, respectively. In addition, three distinct allosteric sites were reported by Schetz and Sibley (2001) for the dopamine $\mathrm{D}_{4}$ receptor. To explore whether HMA and FD-1 compete for the same allosteric binding site, further experiments were conducted. First, the effect of HMA on the displacement of ${ }^{125}$ I-triptorelin by FD-1 was determined (Fig. 8 and Table 4). It was shown that HMA has no competitive interaction with FD-1. However, the allosteric nature of FD-1 only occurs at high concentrations (micromolar range), which makes it difficult to observe an effect of HMA. Second, a 
competitive dissociation assay was performed in which the effect of FD-1 on HMA-induced dissociation was examined. Especially from Fig. 9b, it follows that the presence of FD-1 had no effect on the modulatory potency of HMA. This suggests that FD-1 acts at a site distinct from the binding site of HMA and that there is no interaction between the binding of FD-1 and HMA. To strengthen this, a simulation was performed using a model according to Lazareno et al. (2000). As demonstrated in Fig. 10, HMA and FD-1 indeed have neutral cooperativity $(\delta=1)$. It is quite feasible that other GPCRs modulated by amilorides can also be modulated by a receptor-specific modulator from a second allosteric site. For example, the dopamine $\mathrm{D}_{2}$ receptor, which was earlier shown to be modulated by amiloride analogs (Leppik and Birdsall, 2000), is also influenced allosterically by the tripeptide L-prolyl-L-leucyl-glycinamide (Verma et al., 2005).

In conclusion, we have demonstrated that the $\mathrm{GnRH}$ receptor can be allosterically modulated by amiloride analogs. In addition, FD-1 was shown to have both orthosteric and allosteric binding properties. Furthermore, we demonstrate that these two chemically unrelated compounds have two distinct allosteric binding sites on the human $\mathrm{GnRH}$ receptor and that these sites show neutral cooperativity. The allosteric sites revealed in this study may provide novel targets at the $\mathrm{GnRH}$ receptor for orally available low molecular weight compounds.

\section{Acknowledgments}

We thank Dr. Guido J. R. Zaman (Organon BioSciences, Oss, The Netherlands) for helpful comments and critical reading of the manuscript. We are grateful to Top Institute Pharma (TI Pharma, The Netherlands) for continuation of this project.

\section{References}

Anderes KL, Luthin DR, Castillo R, Kraynov EA, Castro M, Nared-Hood K, Gregory ML, Pathak VP, Christie LC, Paderes G, Vazir H, Ye Q, Anderson MB, and May JM (2003) Biological characterization of a novel, orally active small molecule gonadotropin-releasing hormone $(\mathrm{GnRH})$ antagonist using castrated and intact rats. J Pharmacol Exp Ther 305:688-695.

Armer RE and Smelt KH (2004) Non-peptidic GnRH receptor antagonists. Curr Med Chem 11:3017-3028.

Beckers T, Bernd M, Kutscher B, Kuhne R, Hoffmann S, and Reissmann T (2001) Structure-function studies of linear and cyclized peptide antagonists of the GnRH receptor. Biochem Biophys Res Commun 289:653-663.

Betz SF, Reinhart GJ, Lio FM, Chen C, and Struthers RS (2006) Overlapping, nonidentical binding sites of different classes of nonpeptide antagonists for the human gonadotropin-releasing hormone receptor. J Med Chem 49:637-647.

Bruns RF and Fergus JH (1990) Allosteric enhancement of adenosine $\mathrm{A}_{1}$ receptor binding and function by 2-amino-3-benzoylthiophenes. Mol Pharmacol 38:939949.

Cheng Y and Prusoff WH (1973) Relationship between the inhibition constant $\left(\mathrm{K}_{1}\right)$ and the concentration of inhibitor which causes 50 per cent inhibition $\left(\mathrm{I}_{50}\right)$ of an enzymatic reaction. Biochem Pharmacol 22:3099-3108.

Christopoulos A and Kenakin T (2002) G protein-coupled receptor allosterism and complexing. Pharmacol Rev 54:323-374.

Chu L, Lo JL, Yang YT, Cheng K, Smith RG, Fisher MH, Wyvratt MJ, and Goulet MT (2001) SAR studies of novel 5-substituted 2-arylindoles as nonpeptidyl GnRH receptor antagonists. Bioorg Med Chem Lett 11:515-517.

Conn PM and Crowley WF, Jr. (1994) Gonadotropin-releasing hormone and its analogs. Annu Rev Med 45:391-405.

Cragoe EJ Jr, Woltersdorf OW, Jr., Bicking JB, Kwong SF, and Jones JH (1967) Pyrazine diuretics. II. $N$-Amidino-3-amino-5-substituted 6-halopyrazinecarboxamides. J Med Chem 10:66-75.

DeVita RJ, Hollings DD, Goulet MT, Wyvratt MJ, Fisher MH, Lo JL, Yang YT, Cheng K, and Smith RG (1999) Identification and initial structure-activity relationships of a novel non-peptide quinolone $\mathrm{GnRH}$ receptor antagonist. Bioorg Med Chem Lett 9:2615-2620.

Fromme BJ, Katz AA, Roeske RW, Millar RP, and Flanagan CA (2001) Role of aspartate7.32(302) of the human gonadotropin-releasing hormone receptor in stabilizing a high-affinity ligand conformation. Mol Pharmacol 60:1280-1287.

Furuya S, Matsumoto H, Hayase Y, Suzuki N, and Imada T (1997), inventors; Takeda Chemical Industries Ltd., Furuya S, Matsumoto H, Hayase Y, Suzuki N, and Imada T, assignees. Thienopyridine derivatives, their production and use. World Patent no. WO9741126. 1997 Nov 6.

Gao ZG and IJzerman AP (2000) Allosteric modulation of $\mathrm{A}_{(2 \mathrm{~A})}$ adenosine receptors by amiloride analogues and sodium ions. Biochem Pharmacol 60:669-676.
Göblyös A, de Vries H, Brussee J, and IJzerman AP (2005) Synthesis and biological evaluation of a new series of $2,3,5$-substituted $[1,2,4]$-thiadiazoles as modulators of adenosine $\mathrm{A}_{1}$ receptors and their molecular mechanism of action. $J$ Med Chem 48:1145-1151.

Hoare SR and Strange PG (1996) Regulation of $\mathrm{D}_{2}$ dopamine receptors by amiloride and amiloride analogs. Mol Pharmacol 50:1295-1308.

Horstman DA, Brandon S, Wilson AL, Guyer CA, Cragoe EJ Jr, and Limbird LE (1990) An aspartate conserved among G-protein receptors confers allosteric regulation of alpha 2-adrenergic receptors by sodium. J Biol Chem 265:21590-21595 Imada T, Cho N, Imaeda T, Hayase Y, Sasaki S, Kasai S, Harada M, Matsumoto H, Endo S, Suzuki N, et al. (2006) Design, synthesis, and structure-activity relationships of thieno[2,3-b]pyridin-4-one derivatives as a novel class of potent, orally active, non-peptide luteinizing hormone-releasing hormone receptor antagonists. J Med Chem 49:3809-3825.

Kiesel LA, Rody A, Greb RR, and Szilagyi A (2002) Clinical use of GnRH analogues. Clin Endocrinol $(O x f)$ 56:677-687.

Lanzafame AA, Sexton PM, and Christopoulos A (2006) Interaction studies of multiple binding sites on $\mathrm{m} 4$ muscarinic acetylcholine receptors. Mol Pharmacol 70:736-746.

Lazareno S, Popham A, and Birdsall NJ (2000) Allosteric interactions of staurosporine and other indolocarbazoles with $N$-[methyl- $\left.{ }^{3} \mathrm{H}\right]$ scopolamine and acetylcholine at muscarinic receptor subtypes: identification of a second allosteric site. Mol Pharmacol 58:194-207.

Lefkowitz RJ, De Lean A, Hoffman BB, Stadel JM, Kent R, Michel T, and Limbird L (1981) Molecular pharmacology of adenylate cyclase-coupled alpha- and betaadrenergic receptors. Adv Cyclic Nucleotide Res 14:145-161.

Leppik RA and Birdsall NJM (2000) Agonist binding and function at the human $\alpha_{2 a}$-adrenoceptor: allosteric modulation by amilorides. Mol Pharmacol 58:1091-1099. Lu ZL, Coetsee M, White CD, and Millar RP (2007) Structural determinants for ligand-receptor conformational selection in a peptide $\mathrm{G}$ protein-coupled receptor. J Biol Chem 282:17921-17929.

May LT, Leach K, Sexton PM, and Christopoulos A (2007) Allosteric modulation of G protein-coupled receptors. Annu Rev Pharmacol Toxicol 47:1-51.

Millar RP, Lu ZL, Pawson AJ, Flanagan CA, Morgan K, and Maudsley SR (2004) Gonadotropin-releasing hormone receptors. Endocr Rev 25:235-275.

Neve KA, Cox BA, Henningsen RA, Spanoyannis A, and Neve RL (1991) Pivotal role for aspartate- 80 in the regulation of dopamine D2 receptor affinity for drugs and inhibition of adenylyl cyclase. Mol Pharmacol 39:733-739.

Oosterom J, van Doornmalen EJ, Lobregt S, Blomenrohr M, and Zaman GJ (2005) High-throughput screening using beta-lactamase reporter-gene technology for identification of low-molecular-weight antagonists of the human gonadotropin releasing hormone receptor. Assay Drug Dev Technol 3:143-154.

Pontillo J, Guo Z, Wu D, Struthers RS, and Chen C (2005) Synthesis of aryl-1,2,4 triazine-3,5-diones as antagonists of the gonadotropin-releasing hormone receptor Bioorg Med Chem Lett 15:4363-4366.

Rhoades R and Pflanzer R (1996) Human Physiology. Harcourt Inc., Orlando, FL.

Sasaki S, Cho N, Nara Y, Harada M, Endo S, Suzuki N, Furuya S, and Fujino M (2003) Discovery of a thieno[2,3-d] pyrimidine-2,4-dione bearing a $p$-methoxyurei dophenyl moiety at the 6-position: a highly potent and orally bioavailable nonpeptide antagonist for the human luteinizing hormone-releasing hormone receptor. J Med Chem 46:113-124.

Schally AV, Arimura A, Kastin AJ, Matsuo H, Baba Y, Redding TW, Nair RM, Debeljuk L, and White WF (1971) Gonadotropin-releasing hormone: one polypeptide regulates secretion of luteinizing and follicle-stimulating hormones. Science 173:1036-1038.

Schetz JA and Sibley DR (2001) The binding-site crevice of the D4 dopamine receptor is coupled to three distinct sites of allosteric modulation. J Pharmacol Exp Ther 296:359-363.

Smith PK, Krohn RI, Hermanson GT, Mallia AK, Gartner FH, Provenzano MD, Fujimoto EK, Goeke NM, Olson BJ, and Klenk DC (1985) Measurement of protein using bicinchoninic acid. Anal Biochem 150:76-85

Soudijn W, Van Wijngaarden I, and IJzerman A (2004) Allosteric modulation of G protein-coupled receptors: perspectives and recent developments. Drug Discov Today 9:752-758.

Sullivan SK, Brown MS, Gao Y, Loweth CJ, Lio FM, Crowe PD, Struthers RS, and Betz SF (2006) Allosteric and orthosteric binding modes of two nonpeptide human gonadotropin-releasing hormone receptor antagonists. Biochemistry 45:15327-15337.

Sun ET, Anderson MB, Anderes KL, Christie LC, Do QQ, Feng J, Goetzen T, Hong Y, Iatsimirskaia EA, Li H, et al. (2002), inventors; Agouron Pharma, Anderson MB, Anderes KL, Christie LC, Do QQ, Feng J, Goetzen T, Hong Y, Iatsimirskaia $\mathrm{EA}, \mathrm{Li} \mathrm{H}$, et al., assignees. Non-peptide GnRH agents, pharmaceutical compositions and methods for their use, and processes for preparing them and their intermediates. World Patent no. WO02098363. 2002 Dec 12.

van den Nieuwendijk AMCH, Pietra D, Heitman L, Göblyös A, and IJzerman AP (2004) Synthesis and biological evaluation of $2,3,5$-substituted $[1,2,4]$ thiadiazoles as allosteric modulators of adenosine receptors. J Med Chem 47:663-672.

van der Klein PA, Kourounakis AP, and IJzerman AP (1999) Allosteric modulation of the adenosine $A_{1}$ receptor. Synthesis and biological evaluation of novel 2-amino3-benzoylthiophenes as allosteric enhancers of agonist binding. $J$ Med Chem 42:3629-3635.

Verma V, Mann A, Costain W, Pontoriero G, Castellano JM, Skoblenick K, Gupta SK, Pristupa Z, Niznik HB, Johnson RL, et al. (2005) Modulation of agonist binding to human dopamine receptor subtypes by L-prolyl-L-leucyl-glycinamide and a peptidomimetic analog. J Pharmacol Exp Ther 315:1228-1236.

Address correspondence to: A. P. IJzerman, Division of Medicinal Chemistry, Leiden/Amsterdam Center for Drug Research, University of Leiden, P.O. Box 9502, 2300 RA Leiden, The Netherlands. E-mail: ijzerman@lacdr. leidenuniv.nl 